\title{
Determination of Climate Factors in Flood and Drought Disaster in Indonesia using Instrumental Variable (IV) Methods
}

\author{
Faradiba Faradiba ${ }^{1}$ \\ ${ }^{1}$ Physics Education Study Program, Universitas Kristen Indonesia, Jakarta, Indonesia.
}

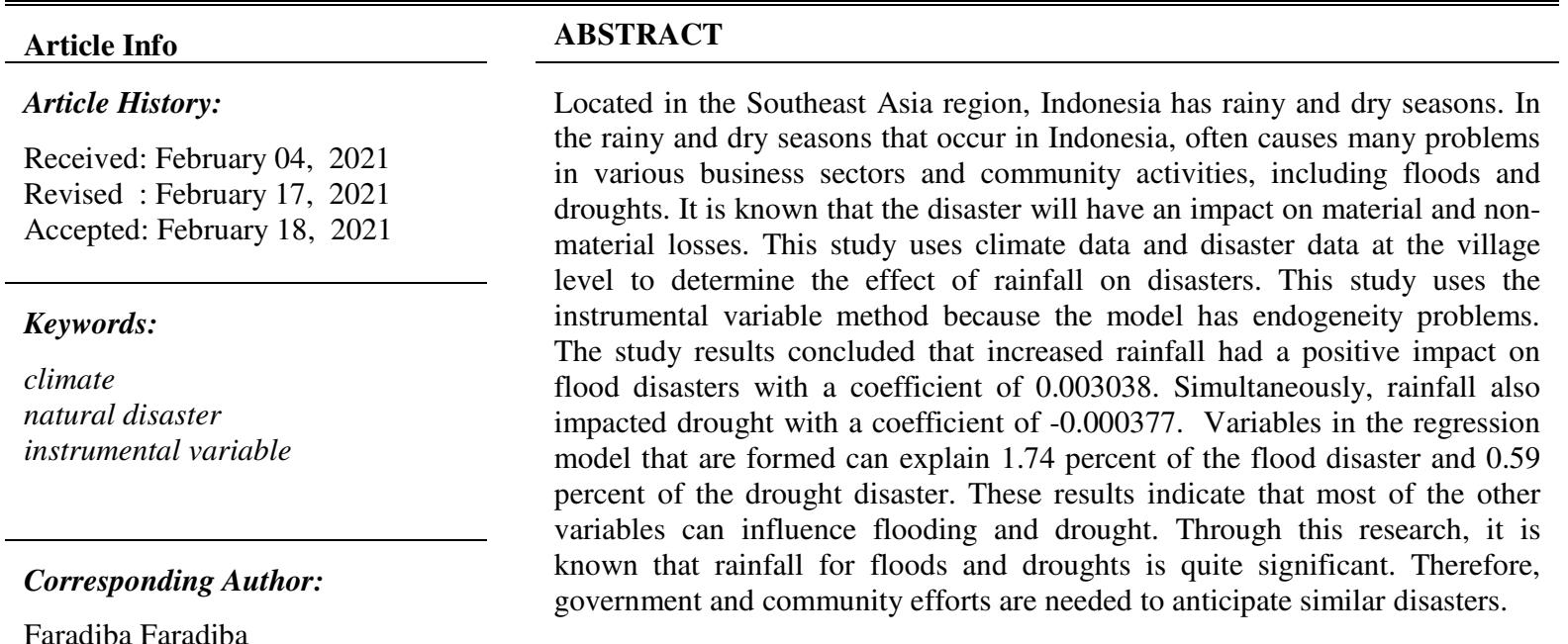

Copyright $@ 2021$ Author(s)

\section{INTRODUCTION}

Flanked by two oceans, namely the Pacific Ocean and the Indian Ocean, Indonesia has two climates every year. The rainy season ranges from October to March, and the dry season from April to September (Mau, 2018). Indonesia's geographical conditions significantly affect the climate conditions that occur, especially with global warming (Faradiba, 2018; Laksmana, 2011; Marfai \& King, 2008).

In Indonesia, extreme climatic conditions often disrupt community activities, thus impacting government programs(Faradiba \& Zet, 2020). Disasters that occur due to extreme weather during the rainy season include floods. Meanwhile, during the dry season, drought often occurs (McSweeney \& Coomes, 2011; Mitchell et al., 2010; Rahman, 2013). The two disasters were affected by the rain that occurred and were opposites.

Flood disasters can be triggered by several natural factors, including prolonged heavy rains, silting rivers, and high tides (Chatterjee, 2010; Manawi et al., 2020; Trysnyuk et al., 2018). In addition, flood disasters can also be triggered by human actions, such as littering into waterways. In a short time, this may not cause significant harm, but the behavior of littering carried out by many people and carried out continuously will cause disaster.

In contrast to floods, during the dry season, Indonesia is often hit by drought. Drought is caused by a lack of rain intensity that flushes an area(Potts, 2003; Rouault \& Richard, 2003). In addition, drought disasters can also be prevented through "loving the environment" behavior by creating greenery around the house (Ryan, 2011). When the whole community carries out this behavior, the natural ecosystem will tend to be better preserved. 
Faradiba: Determination of Climate Factors in Flood and Drought Disaster in Indonesia

Flood and drought disasters are frequent disasters in Indonesia, directly caused by the intensity of rainfall (Asy'ari, 2018; Pratiwi \& Nugraha, 2016). Disasters that occur will cause material and nonmaterial losses, such as damage to houses, casualties, wounded victims; even a few disasters will cause poverty and disrupt regional development (Cherniack, 2008; Panwar \& Sen, 2019; Toya \& Skidmore, 2007).

Based on previous research, it is known that climate affects natural disasters (Banholzer et al., 2014; Benevolenza \& DeRigne, 2019; Van Aalst, 2006). Previous research has used data at both the state and provincial levels. This study used data at the village level. From this research, the effect of rainfall on floods and drought in Indonesia will be known.

\section{METHOD}

The data used in this study is the raw data from PODES 2018 data collection, which describes the conditions of flood and drought disasters at the village level from 2015 to 2017. PODES data collection is organized by BPS and is specifically designed to collect data that can describe conditions in rural areas and urban villages, and prepare the upcoming census through the collected data and information.

The unit of analysis in this research is definitive villages and urban village according to the following provisions: (i) there is a village/urban village area with clear boundaries, (ii) there are residents who live in the village/urban village area, (iii) There is a village/urban village government (BPS, 2018). The number of observations used in the study was 83,931 villages.

This study uses rainfall data as a variable of interest. The instrument variables in this study were wind speed, humidity, and temperature. This study also uses several control variables, namely villages bordering the sea, villages in forest areas, water pollution, soil pollution, and air pollution.

This study uses the Instrumental Variable (IV) method because built model has an endogeneity problem. Wooldridge (2016) states that instrumental variable analysis is used to overcome the problem of endogeneity. The Ordinary Least Square (OLS) estimator will be biased and inconsistent if a critical variable is not included in the model. Coefficients IV and OLS will be compared in this study. According to the theory, the IV coefficient will be greater than OLS. Suppose there is a simple regression equation like the following:

$$
y=\beta_{0}+\beta_{i} x+u
$$

where $x$ and $u$ correlated or $\operatorname{Cov}(x, u) \neq 0$, hence the OLS method cannot be used. This is known as endogeneity. Order an estimator $\beta_{0}$ and $\beta_{1}$ consistent when $x$ and $u$ correlated, then additional information is needed by adding new variables that fulfill certain properties. The new variable (say $Z$ ) must meet two assumptions, namely: (i) Variable $z$ uncorrelated with $u \operatorname{Cov}(z, u)=0$. This assumption is called the exogeneity instrument; and (ii) Variable $z$ correlated with $x$ or $\operatorname{Cov}(z, x) \neq 0$. This assumption is called the relevance instrument. The variable $z$ is called the instrumental variable for the variable $x$ or the instrument for the variable $x$. Furthermore, the variable $x$, which is said to be an endogenous variable, raises the following regression equation:

$$
x=\pi_{0}+\pi_{i} x+z+v
$$

Table 1. OLS and IV estimation results on the number of floods and droughts during the 2015-2017 period

\begin{tabular}{lllll}
\hline \multirow{2}{*}{ Description } & \multicolumn{2}{l}{ Floods } & Droughts \\
\cline { 2 - 5 } & OLS & IV & OLS & IV \\
\hline Rainfall & -0.000084 & $0.003038^{* * *}$ & $-0.000369^{* * *}$ & $-0.000377^{* * *}$ \\
Control Variable & Yes & & & \\
Instrument Variable & No & Yes & No & Yes \\
$R^{2}$ & 0.0205 & 0.0174 & 0.0059 & 0.0059 \\
Observation & 83,931 & & & \\
\hline
\end{tabular}

Note: Notation level of significance $* * * p<1 \%$. 


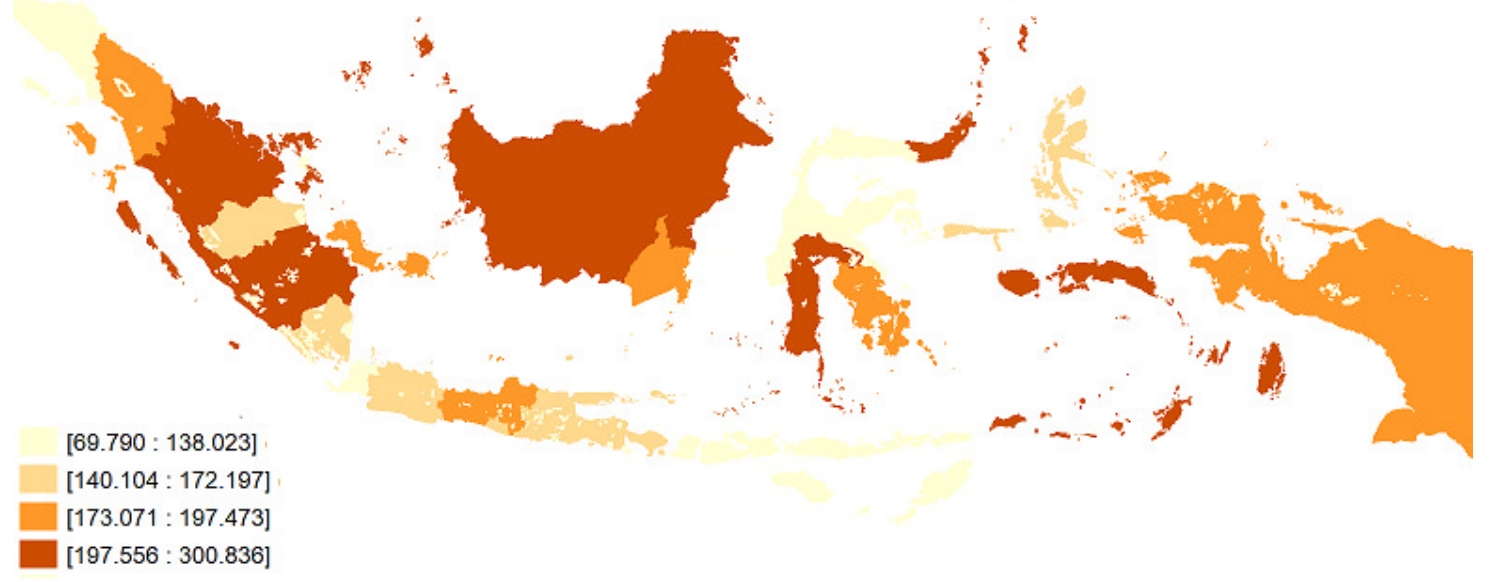

(a)

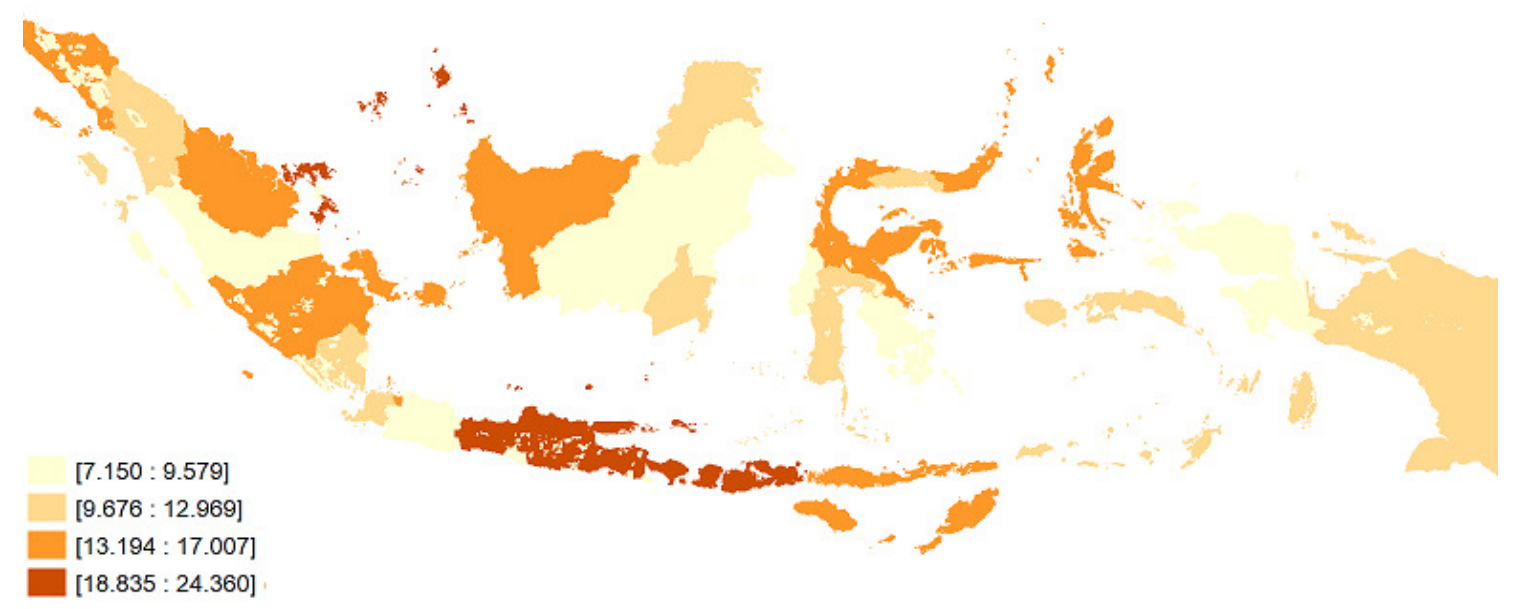

(b)

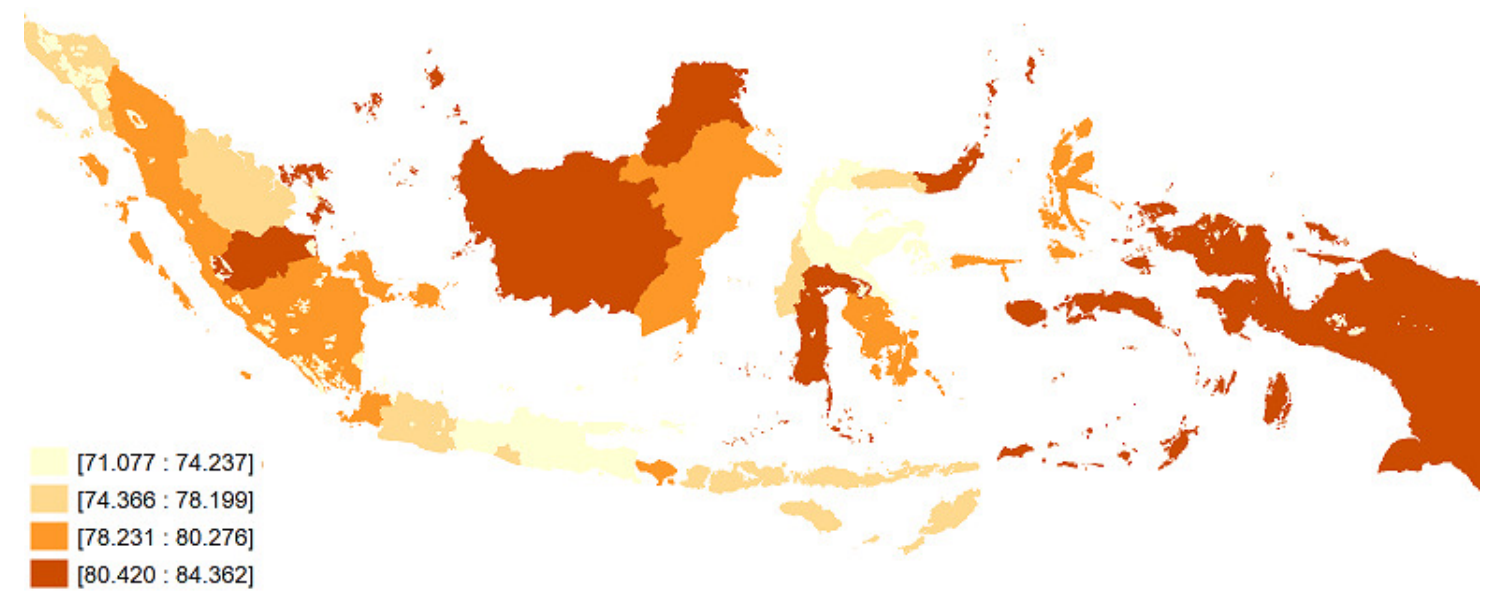

(c)

Figure 1. Climate Conditions in Indonesia (a) Rainfall, (b) Wind velocity, and (c) Humidity 


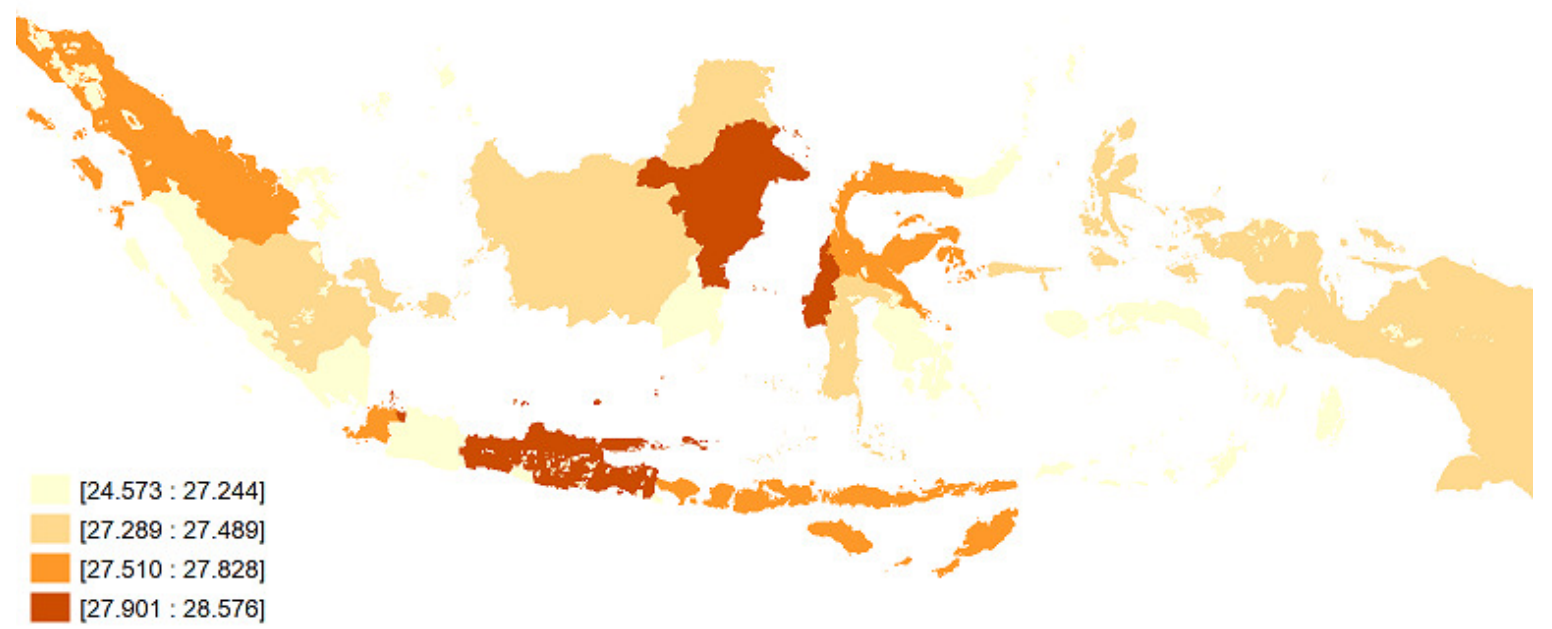

(d)

Figure 1. (continued) (d) Temperature

Gujarati \& Porter (2009) said that the IV method is carried out in two stages. The first stage is to regress equation (2) and predict the value of the variable $x$ which is denoted by $\hat{x}$. The second stage is to enter the variable value $\hat{x}$ into equation (1) and perform regression using OLS. This second stage estimate is an estimator from IV method, which is consistent and unbiased. The models to be built in this study are:

First stage model

rainfall $=\alpha+\beta_{1}$ wind $_{\text {velocity }}+\beta_{2}$ humidity $+\beta_{3}$ sunshine $+\beta_{4}$ temperature $+\beta_{5}$ air $_{\text {pressure }}$

$$
+\beta_{i} X_{i}+\varepsilon
$$

Floods OLS model

Floods $=\alpha+$ rainfall $+\beta_{1}$ sea $_{\text {border }}+\beta_{2}$ forest $_{\text {area }}+\beta_{3}$ water $_{\text {pollution }}+\beta_{4}$ soil $_{\text {pollution }}+$

$$
\beta_{5} \text { air pollution }+\beta_{i} X_{i}+\varepsilon
$$

Floods IV model

$$
\begin{gathered}
\text { Floods }=\alpha+\text { rainfall }+\beta_{1} \text { sea }_{\text {border }}+\beta_{2} \text { forest }_{\text {area }}+\beta_{3} \text { water }_{\text {pollution }}+\beta_{4} \text { soil }_{\text {pollution }}+ \\
\beta_{5} \text { air } \text { pollution }+\beta_{i} X_{i}+\varepsilon
\end{gathered}
$$

Droughts OLS model

Droughts $=\alpha+$ rainfall $+\beta_{1}$ sea $_{\text {border }}+\beta_{2}$ forest $_{\text {area }}+\beta_{3}$ water $_{\text {pollution }}+\beta_{4}$ soil $_{\text {pollution }}+$

$$
\beta_{5} \text { air pollution }+\beta_{i} X_{i}+\varepsilon
$$

Droughts IV model

Droughts $=\alpha+$ rainfall $+\beta_{1}$ sea $_{\text {border }}+\beta_{2}$ forest $_{\text {area }}+\beta_{3}$ water $_{\text {pollution }}+\beta_{4}$ soil pollution +

$$
\beta_{5} \text { air pollution }+\beta_{i} X_{i}+\varepsilon
$$




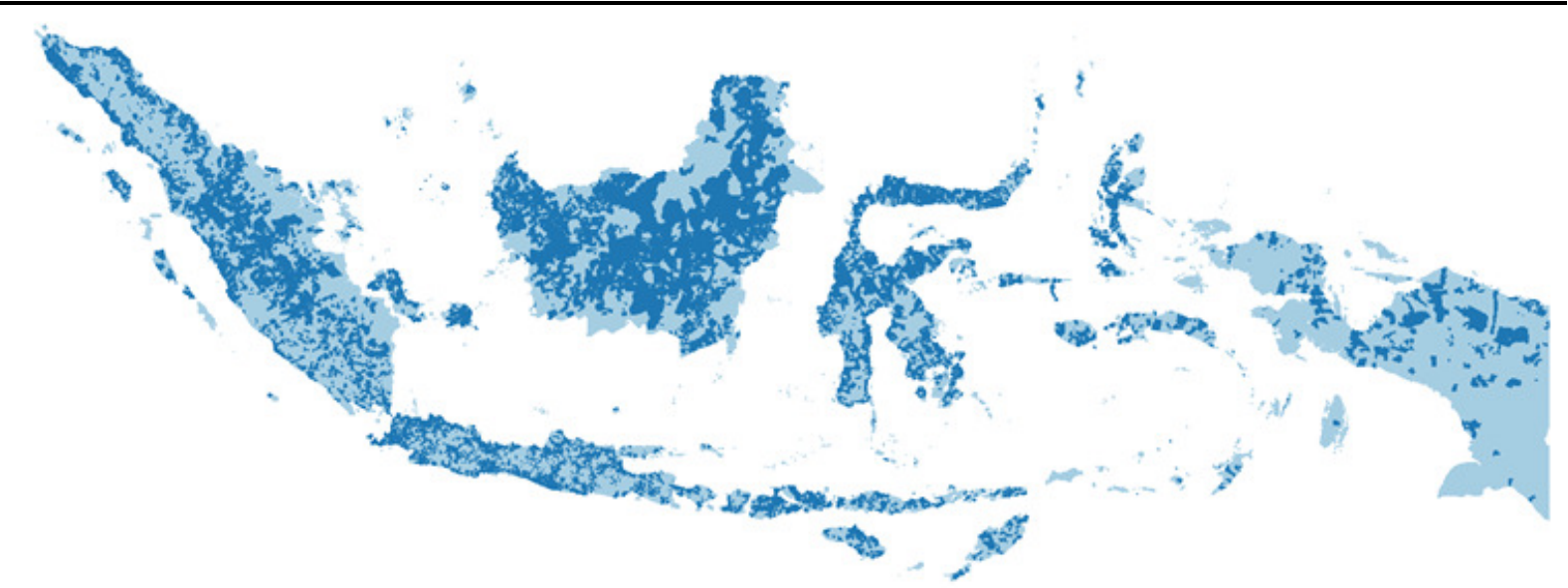

(a)

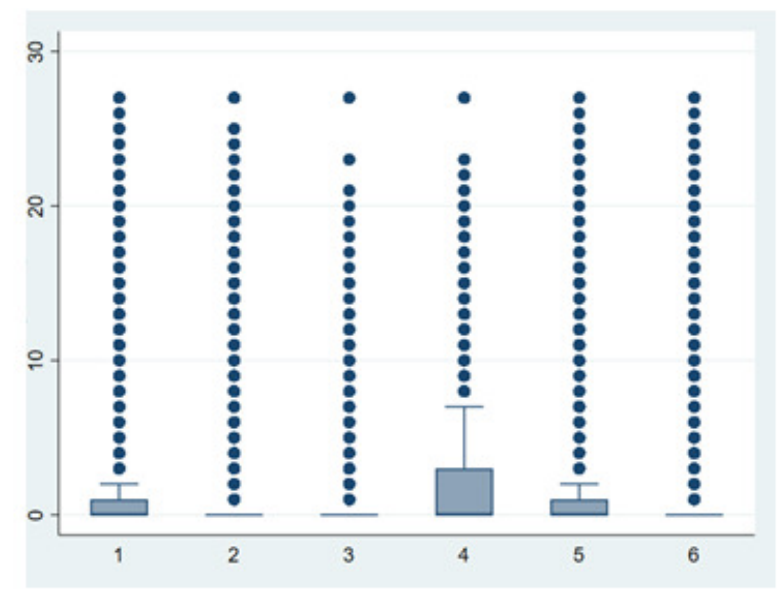

(b)

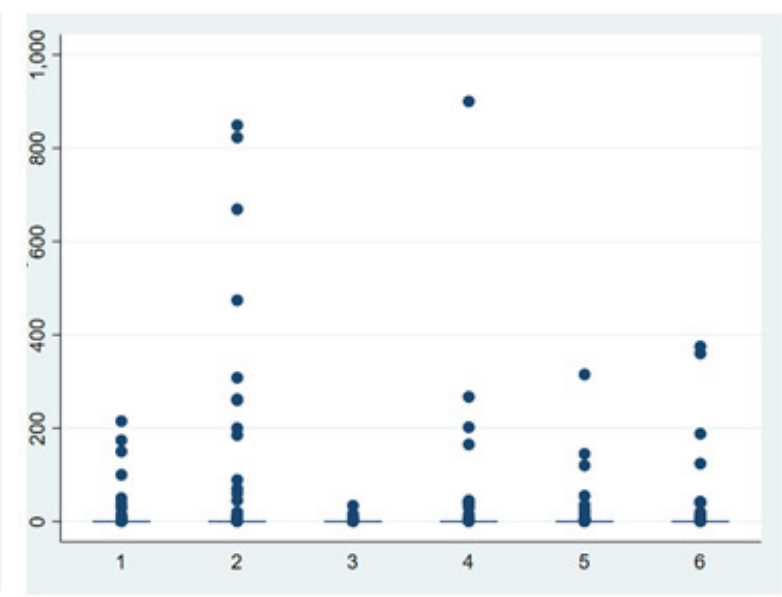

(c)

Figure 2. Flood Disaster Condition in Indonesia (a) The existence of a flood disaster, (b) Range of number of flood disasters experienced by the and (c) The range of the number of deaths due to flood experienced by the village

\section{RESULTS AND DISCUSSION}

There are differences in geography position, causing differences in climate in Indonesia. From Figure 1, it is known that the rainfall on Kalimantan Island is the highest, while Java Island has the highest wind speed. In addition, Kalimantan Island is an island with high humidity, and Java Island has a high temperature. Apart from different geographical positions, regional characteristics (such as population density, regional economy, and the main source of income for the community) can also influence climate conditions that occur in an area.

From the results of regression calculations using the instrumental variable method, in Table 1, it is known that rainfall has a positive effect on flood disasters as well as a negative effect on drought disasters. These results are in line with the previous study (Ralph et al., 2003; Verschuren et al., 2000). This indicates that the variable of rainfall, such as two blades. In the dry season, high rainfall is needed for the source of life for the community. The existence of a prolonged dry season causes people to get clean water. This business can take the form of fetching water that is located further away or paying for water. This condition must be done because water is a basic need for households.

The calculation using the instrumental variable method is greater than the calculation using the ordinary least square method. This is in accordance with the theory presented that the instrumental variable method will solve the endogeneity problem and if traced, the coefficient formed will be greater than the ordinary least square method (Wooldridge, 2016). 
From the regression results using the OLS and IV methods, it is known that, from Table 1, it can be interpreted that the variables in the regression model that are formed can explain 1.74 percent of the flood disaster and 0.59 percent of the drought disaster. These results indicate that most other variables can influence the occurrence of floods and droughts. Other things that can affect these disasters include local governments' role in controlling extreme weather and community behavior in protecting the environment (Porter et al., 2015).

Based on Figure 2a, it is known that villages in Papua Island tend to experience a few flood disasters, in contrast to other islands that experience flooding in almost all regions. This is in accordance with the condition of the land on the Papua Island, which is still natural so that water absorption can function optimally (Kurika et al., 2019; Vines, 1970). In addition, the level of population density is still relatively low, resulting in the availability of large water catchment areas.

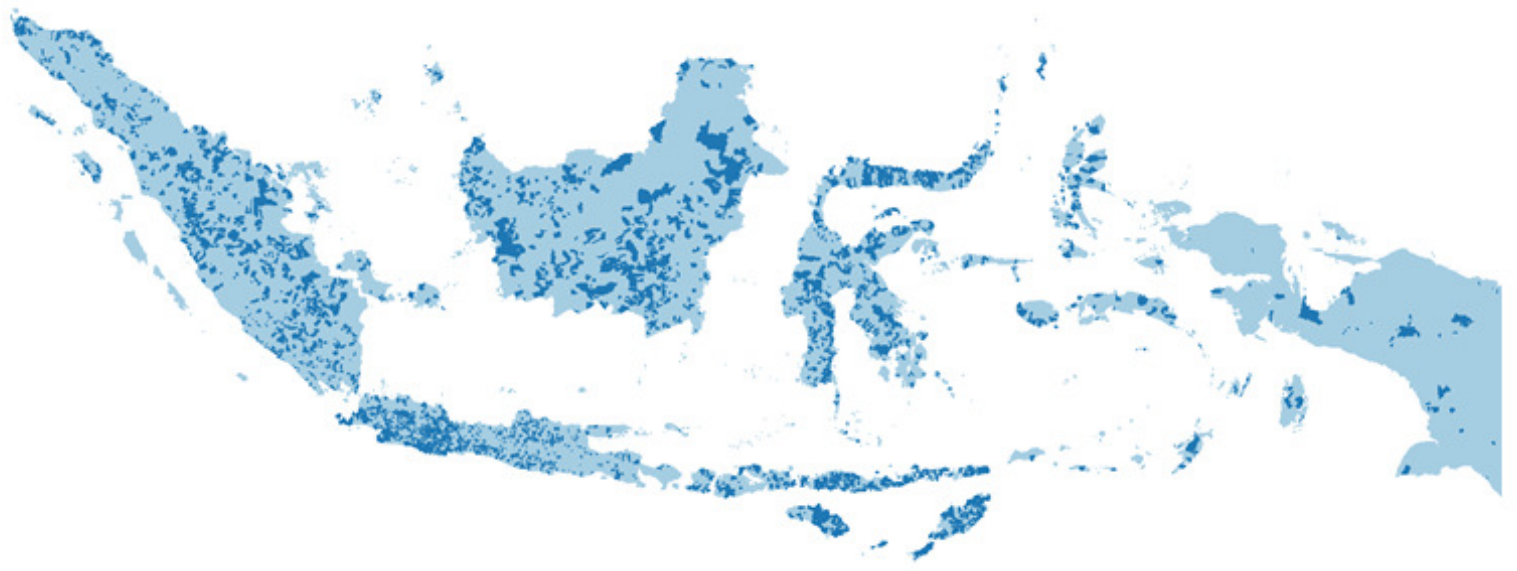

(a)

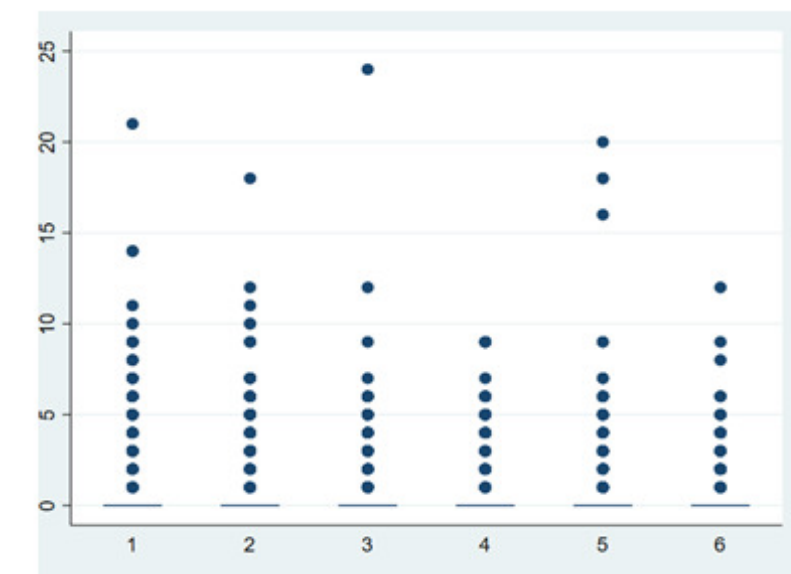

(b)

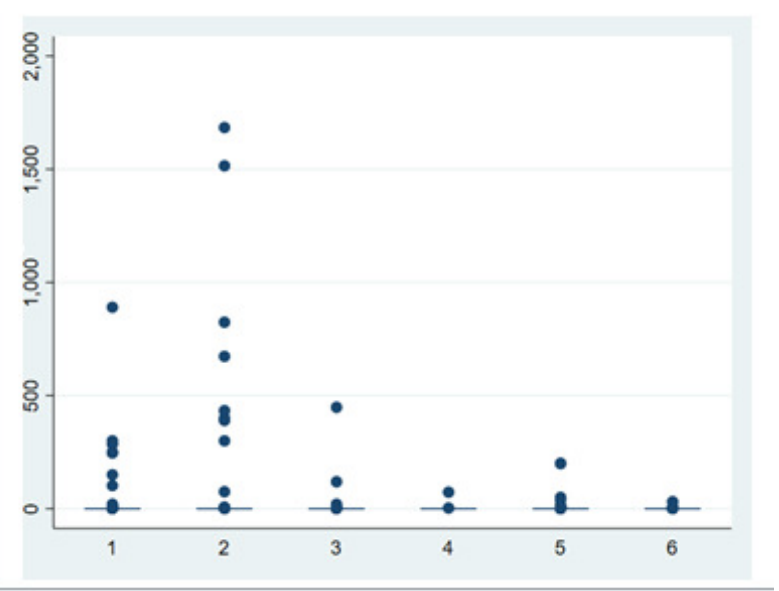

(c)

Figure 3. Drought Disaster Conditions in Indonesia (a) The existence of a drought disaster, (b) Range of number of drought disasters experienced by the village and (c) The range of the number of deaths due to drought experienced by the village

When viewed from the number of casualties, the islands of Java and Kalimantan have a record number of casualties. This can occur due to the high population density in the area so that the drought has a significant impact. Based on Figure 2b, it can also be seen that Kalimantan Island has a history of flood disasters during the last three years, mostly in the range below three events for each village 
experienced it. This number is relatively evenly distributed in most of the villages in Kalimantan Island which were hit by the flood.

Based on Figure 3a, it is known that villages in Maluku and Papua islands tend to experience a few drought disasters, in contrast to other islands that experience drought in almost all regions. This is in accordance with the land condition on the island of Papua, which is still natural so that water absorption can function optimally. In addition, the level of population density is relatively low, resulting in the availability of groundwater sources that can meet the needs of local communities. When viewed from the number of casualties, Java Island has a record of many victims. This can occur due to the high population density in the area, so that the drought has a big impact. Based on Figure $3 \mathrm{~b}$, it can also be seen that the islands of Bali and Nusa Tenggara, Sumatra, and Sulawesi have a history of drought during the last three years, with more than 20 drought disasters.

Efforts are needed to resolve the annual disasters that often hit villages in Indonesia. The government needs to work with local communities to reduce and even eliminate these disasters. Disasters caused by high or low rainfall cannot be regulated. However, mitigation to anticipate disasters needs to be made to minimize material and non-material casualties. Education related to the environment is also needed to increase public insight about the importance of the environment in the source of life. In the short term, the disaster may not yet be seen, but the disgraceful behavior of the community will cause a disaster in the long term (Sadiq \& Noonan, 2015). Community behavior that can cause climate disruption, among others, is pollution due to business activities, burning fields, use of air conditioners, and the cessation of the culture of planting trees in the yard.

In this study, the climate variable is still used at the measurement station level, limited in number at the provincial level. It is hoped that future studies can use climate indicators at the village level, so that the analysis can be a more representative conclusion.

\section{CONCLUSION}

Disasters caused by natural factors often cause harm to society. This event usually occurs every year. This study indicates that areas that have high interaction, mobility, and population have a relatively high incidence of disasters. The regression results show that an increase in each unit of rainfall will provide an opportunity for a flood disaster of 0.003038 . On the other hand, an increase in rainfall during the dry season will reduce the chance of a drought disaster by -0.000377 . This is due to disruption of the environmental ecosystem, which results in disasters. From the results of rainfall analysis, it is known that an increase in rainfall has a positive impact on flood disasters, and simultaneously rainfall also has an impact on drought. Through this phenomenon, it can be concluded that Indonesia's climate can cause disasters, both during the rainy and dry seasons. This will become more concentrated when an area has an extremely rainy and dry season. This condition has usually been going on for the last few years. Government and community efforts are needed to anticipate similar disasters. One of the efforts that can be made to control climate is through people's behavior in carrying out their daily activities.

\section{ACKNOWLEDGEMENT}

The author would like to thank the editorial team of the Jurnal Ilmu Fisika (JIF) and two anonymous reviewers.

\section{REFERENCE}

Asy'ari, Q. (2018). Analisis Dampak Sosial Ekonomi Pasca Bencana Di Kabupaten Pamekasan (Studi Kasus Banjir, Longsor dan Kekeringan di Pamekasan 2007). J-MACC: Journal of Management and Accounting, 1, 2, 153-168.

Banholzer, S., Kossin, J., \& Donner, S. (2014). The impact of climate change on natural disasters. In Reducing disaster: Early warning systems for climate change (21-49). Springer.

Benevolenza, M. A., \& DeRigne, L. (2019). The impact of climate change and natural disasters on vulnerable populations: A systematic review of literature. Journal of Human Behavior in the Social Environment, 29, 2, 266-281. 
Faradiba: Determination of Climate Factors in Flood and Drought Disaster in Indonesia

BPS. (2018). Statistik Potensi Desa.

Chatterjee, M. (2010). Slum dwellers response to flooding events in the megacities of India. Mitigation and Adaptation Strategies for Global Change, 15, 4, 337-353.

Cherniack, E. P. (2008). The impact of natural disasters on the elderly. American Journal of Disaster Medicine, $3,3,133-139$.

Faradiba, F., \& Zet, L. (2020). The Impact of climate factors, disaster, and social community in rural development. The Journal of Asian Finance, Economics and Business, 7, 9, 707-717. https://doi.org/https://doi.org/10.13106/jafeb.2020.vol7.no9.707

Faradiba, F. (2018). Peramalan Curah Hujan dan Luas Serangan Organisme Pengganggu Tanaman Di Kabupaten Bogor. Pro-Life, 5, 3, 688-699.

Gujarati, D. N., \& Porter, D. (2009). Basic Econometrics Mc Graw-Hill International Edition.

Kurika, L. M., Lolo, M., \& Moxon, J. E. (2019). Agricultural research and development on small islands and atolls: The Papua New Guinea experience.

Laksmana, E. A. (2011). Indonesia's rising regional and global profile: does size really matter? Contemporary Southeast Asia, 157-182.

Manawi, S. M. A., Nasir, K. A. M., Shiru, M. S., Hotaki, S. F., \& Sediqi, M. N. (2020). Urban Flooding in the Northern Part of Kabul City: Causes and Mitigation. Earth Systems and Environment, 4, 3, 599-610.

Marfai, M. A., \& King, L. (2008). Potential vulnerability implications of coastal inundation due to sea level rise for the coastal zone of Semarang city, Indonesia. Environmental Geology, 54, 6, 1235-1245.

Mau, F. (2018). Hubungan Antara Curah Hujan dan Temperatur dengan Malaria di Kabupaten Sumba Barat Daya Provinsi Nusa Tenggara Timur-Indonesia. Buletin Penelitian Kesehatan, 46, 2, 129-134.

McSweeney, K., \& Coomes, O. T. (2011). Climate-related disaster opens a window of opportunity for rural poor in northeastern Honduras. Proceedings of the National Academy of Sciences, 108, 13, 5203-5208.

Mitchell, T., Ibrahim, M., Harris, K., Hedger, M., Polack, E., Ahmed, A. K., Hall, N., Hawrylyshyn, K., Nightingale, K., \& Onyango, M. (2010). Climate smart disaster risk management.

Panwar, V., \& Sen, S. (2019). Economic impact of natural disasters: An empirical re-examination. Margin: The Journal of Applied Economic Research, 13(1), 109-139.

Porter, J. J., Demeritt, D., \& Dessai, S. (2015). The right stuff? Informing adaptation to climate change in British local government. Global Environmental Change, 35, 411-422.

Potts, M. D. (2003). Drought in a Bornean everwet rain forest. Journal of Ecology, 91(3), 467-474.

Pratiwi, R. D., \& Nugraha, A. L. (2016). Pemetaan Multi Bencana Kota Semarang. Jurnal Geodesi Undip, 5, 4, $122-131$.

Rahman, M. S. (2013). Climate change, disaster and gender vulnerability: A study on two divisions of Bangladesh. American Journal of Human Ecology, 2, 2, 72-82.

Ralph, F. M., Neiman, P. J., Kingsmill, D. E., Persson, P. O. G., White, A. B., Strem, E. T., Andrews, E. D., \& Antweiler, R. C. (2003). The impact of a prominent rain shadow on flooding in California's Santa Cruz Mountains: A CALJET case study and sensitivity to the ENSO cycle. Journal of Hydrometeorology, 4, 6, 1243-1264.

Rouault, M., \& Richard, Y. (2003). Intensity and spatial extension of drought in South Africa at different time scales. Water $S a, 29,4,489-500$.

Ryan, M. G. (2011). Tree responses to drought. Tree Physiology, 31(3), 237-239.

Sadiq, A.-A., \& Noonan, D. (2015). Local capacity and resilience to flooding: community responsiveness to the community ratings system program incentives. Natural Hazards, 78, 2, 1413-1428.

Toya, H., \& Skidmore, M. (2007). Economic development and the impacts of natural disasters. Economics Letters, 94, 1, 20-25.

Trysnyuk, V., Trysnyuk, T., Shumeiko, V. O. V., \& Nikitin, A. (2018). Cartographic Models of Dniester River Basin Probable Flooding. Scientific Bulletin Series D: Mining, Mineral Processing, Non-Ferrous Metallurgy, Geology and Environmental Engineering, 32, 1, 51-55.

Van Aalst, M. K. (2006). The impacts of climate change on the risk of natural disasters. Disasters, 30, 1, 5-18.

Verschuren, D., Laird, K. R., \& Cumming, B. F. (2000). Rainfall and drought in equatorial east Africa during the past 1,100 years. Nature, 403, 6768, 410-414.

Vines, A. P. (1970). An epidemiological sample survey of the highlands, mainland and islands regions of the Territory of Papua and New Guinea. An Epidemiological Sample Survey of the Highlands, Mainland and Islands Regions of the Territory of Papua and New Guinea.

Wooldridge, J. M. (2016). Introductory econometrics: A modern approach. Nelson Education. 